E Q U I L I B R I U M

2 ( 5 ) 2010

ISSN 1689-765X

Ilona Pietryka

\title{
The Efficiency of the Monetary Policy Instruments of the European Central Bank in Liquidity Regulating in the Euro Area
}

Key words: Euro area, banking system liquidity

\begin{abstract}
The Mechanism of forming of the liquidity level of national central banks participating in ESCB is clear. It is based on centralized and decentralized operations. The ECB decides on the direction of the monetary policy, and the national central banks implement the monetary policy taking into account those guidelines as well as the conditions of their country. The aim of the paper is to estimate the efficiency of the EBC monetary policy in regulating the liquidity of the banking system in the Euro area. The aim was achieved by characterizing the organizational and balance relationship banks of the Eurosystem because of this regulation. Special emphasis was placed on monetary policy instruments, which are created by the national central banks. The banks also form the liquidity of the Euro area.
\end{abstract}

\section{INTRODUCTION}

Since $1^{\text {st }}$ January 2007 the European Union has comprised 27 countries $^{1}$. Sixteen of them ${ }^{2}$ have introduced the single currency euro and have established the so-called euro zone, a geographical area in which the euro is the binding currency. The national central banks $(\mathrm{NCB})$ of these countries create part of the European System of Central Banks (ESCB). According to the Maastricht Treaty, this system is formed of the NCBs EU Member States and the European Central Bank (ECB). To avoid confusion, and for greater transparency of the ESCB's

${ }^{1}$ Belgium, France, Netherlands, Luxembourg, Germany, Italy (founding countries), the United Kingdom, Ireland, Denmark (since 1973), Greece, Spain, Portugal (since 1981), Austria, Finland, Sweden (since 1995), Cyprus, the Czech Republic, Estonia, Latvia, Lithuania, Malta, Poland, Slovakia, Slovenia, Hungary (since 1.05.2004), Bulgaria, Romania (since 1.01.2007).

${ }^{2}$ Belgium, France, the Netherlands, Luxembourg, Germany, Italy, Ireland, Greece, Spain, Portugal, Austria, Finland (since 1.01.1999), Slovenia (since 1.01.2007 r.), Cyprus, Malta (from 1.01.2008), Slovakia (since 1.01.2009). 
structure, the term Eurosystem has been introduced. This concept includes the ECB and the NCBs of those EU member states which have already introduced the euro. Currently, eleven countries stay outside the euro zone (three 'old' and eight 'new' EU member states). Eight of them (excluding Denmark and UK) have the status of countries with derogation and they will be able to join this region only after they meet the convergence criteria. The following terms: the Eurosystem and the ESCB will co-exist as long as all the EU Member States do not join the Euro area - then the Eurosystem will have become synonymous with the ESCB.

In the Euro area money is created by a financial institution forming the twotier banking system. NBC is the first level - it creates cash money, and the second is formed by the other monetary financial institutions, in the ECB's publications called as credit institutions, i.e., banks. They, in turn, create non-cash money ${ }^{3}$.

Money is an endogenous phenomenon that co-creates the whole economic order. The creation cannot be arbitrary, and because of this fact it is formed by the monetary policy. In the Euro area there exists a peculiar mechanism of liquidity regulation. It is based on the uniformed rules set by the Governing Council for each country of the Eurosystem. This is a very important issue due to the fact that the non-cash money dominates today. The stock of this money presents over $90 \%$ of the monetary aggregate M3 in the countries of the Euro area, which is the total amount of money held in the hands of the non-banking sector'.

Adjusting the liquidity level is carried out in two stages. The NBCs send to the ECB their own forecasts concerning the forming of the so-called autonomous position (independent from the conducted monetary policy). Based on these forecasts, the level of liquidity is estimated, which then is reflected in the decisions concerning the direction of the monetary policy, made by the Governing Council. In the second stage the NBCs in line with the Governing Council's directives, using the available instruments, shape the liquidity of banks operating in the country.

The aim of this paper is to systematize factors determining the liquidity of the Eurosystem with particular emphasis on the ECB monetary policy in regulating the liquidity of the banking system in the Euro area. The aim was achieved

${ }^{3}$ Since March 2002 in order to bring banking to the reporting requirements of the ECB, in Poland, a similar classification for sector entities have been applied - in division into financial sector (monetary financial institutions, namely, the central bank and commercial banks, financial institutions and pension funds and other financial intermediaries) and non-financial sector (state enterprises and companies, private enterprises and companies and cooperatives, entrepreneurs and individual farmers, individuals, non-profit institutions serving households) - more on this in: NBP (2002), Information Bulletin 3/2002, Warsaw, pp. 85-87.

${ }^{4}$ At the end of June 2009 the non-cash resources in the Euro area accounted for $92.2 \%$ of the total of M3 (Monthly Bulletin, September 2009, ECB, p. 19). 
by characterization of the organizational and balance linkages of banks in the Eurosystem because of this regulation. The emphasis was placed on the monetary policy instruments, which are created by the national central banks, and which form the liquidity conditions in the Euro area.

\section{Mechanism of Forming THE LiQuidity LEVEL OF THE NATIONAL CENTRAL BANKS PARTICIPATING IN THE ESCB}

The consolidated balance sheet of the Eurosystem enables an ex ante analysis of the liquidity level (see Table 1). On this basis the ECB analyzes liquidity from the demand and supply side and explores the impact of the monetary policy's instruments on the credit institutions in the Euro area. It has a characteristic structure, which is the result of the mechanism described above, and its observation can highlight the areas of impact, resulting from cooperation.

In a consolidated balance sheet there are three groups: the autonomous factors, monetary policy instruments and contributions (deposits) of other monetary financial institutions collected on current accounts in their central banks.

The factors defined as autonomous have an impact on the liquidity of banking system, but generally they are not the result of the monetary policy instruments. On their basis, the guidelines for the desired level of liquidity have been formulated, because they are determined by the behavior of the public (ECB, 2002, p. 42). In the assets column one autonomous factor is distinguished: net foreign assets, and three on the liabilities: banknotes in circulation, government deposits and other net factors. Net foreign assets are foreign currency assets held by the central bank reduced by any liabilities denominated in foreign currency. Their source is the foreign exchange recognized in current and capital turnover of balance of payments 5 . If the Eurosystem buys foreign assets it increases the liquidity of the banking sector and, thereby, reduces the need to conduct operations of monetary policy in this direction. Banknotes in circulation is the total value of banknotes put into circulation by the central bank at the request of credit institutions. It is the largest item in the liabilities column. Banknotes in circulation absorbs the liquidity of the banking system, because it must be obtained from the central bank and in connection with this, credit institutions makes loans. The capital of national treasure of individual states, that is stored on the current accounts in national central banks, is included in government deposits. Other net factors included in the liabilities of the consolidated balance sheet of the Eurosystem, present a composite position, consisting of other previously not

\footnotetext{
${ }^{5}$ Net foreign assets are composed of gold bullion and gold receivables. Claims on the noneuro area and the Euro area residents denominated in foreign currency reduced by liabilities to the Euro area and non-euro area credit institutions related to monetary policy operations denominated in euro and the equivalent of special drawing rights (SDRs) allocated by the IMF.
} 


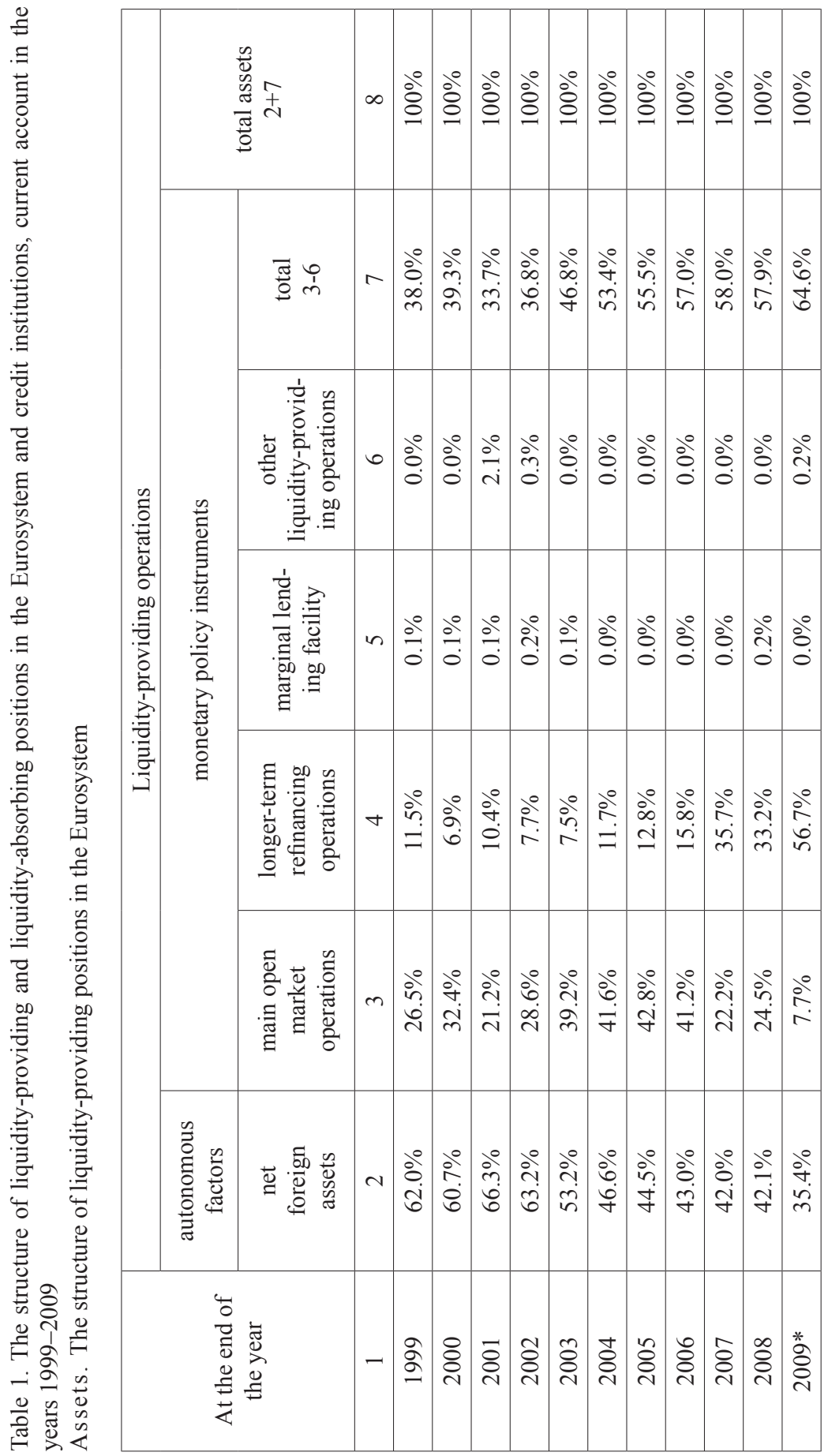




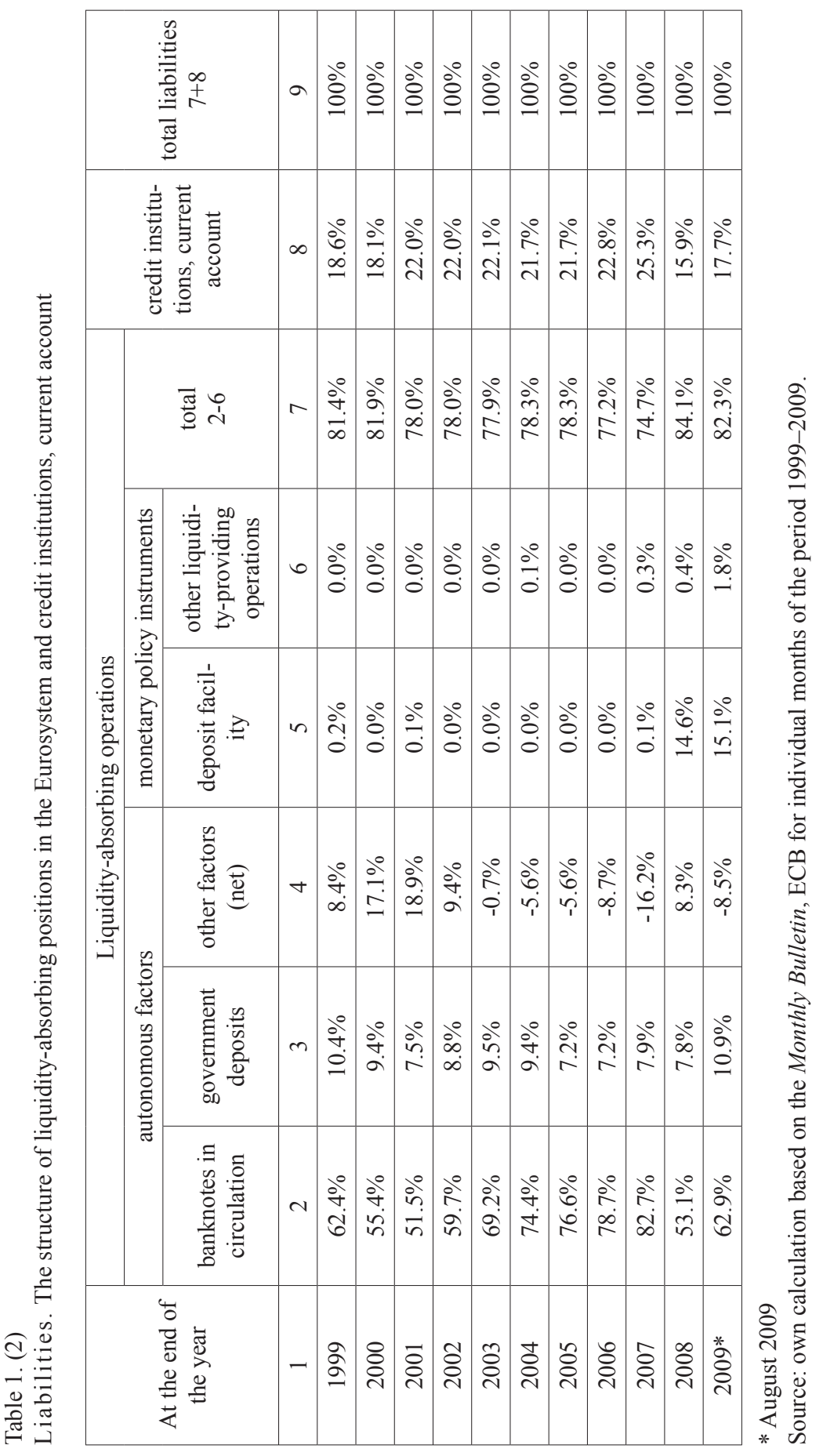


included ingredients of the national central banks' balance sheets. Banknotes in circulation and government deposits are transferred fully from the balance sheets of national central banks (Mazur, Mazur, 2007, pp. 111-114).

The monetary policy instruments are the second group. There are four types of liquidity-providing instruments (Main and longer-term refinancing operations, marginal lending facility and other liquidity-providing operations) and two tools, which are designed to absorb the liquidity (deposit facility and other liquidity-absorbing operations). This is due to the fact that the ECB suffers from reducing the shortage of liquidity in the banking system, and for this purpose in its instrumentation there is a superiority of the liquidity-providing instruments. The refinancing operations group includes main and long-term open market operations. This group also included (if they are carried) liquidity-providing fine-tuning and structural operations. Marginal lending facility is a one-day loan granted by the central bank to credit institutions, which have temporary problems with liquidity deficit and cannot or do not want to choose a cheaper form of refinancing. Deposit facility is an amount of the cheapest one-day deposit which credit institutions of the Eurosystem may set up in central banks in the case of excess liquidity (Mazur, Mazur, 2007, pp. 111-114).

The third specific group is the credit institution's current account. It is the capital owned by banks, which is stored in a central bank in order to comply with the obligation to transfer the minimum reserve requirement and settlement of interbank transactions. This item was not included in the group of instruments of monetary policy, as well as factors unrelated to monetary policy, and is regarded by the ECB as counterbalanced position assets with liabilities in the consolidated balance sheet of the Eurosystem. The increase in any item on the assets side means injection of liquidity in the euro zone, while the increase in autonomous factors or instruments in the liabilities is a signal to absorb liquidity (Paluszak, 2008, p. 50).

According to the ECB's opinion, expressed in 1999, the minimum reserve fulfills two tasks. The most important is the stabilization of the interest rates in the money market. In order to reach the goal, the minimum reserve system was averaged and delayed. Thus, credit institutions can manage better their liquidity, because temporary deviations of reserve from the level required by the central bank may be compensated by reverse deviations in the same reserve maintenance period. Consequently, banks may use the moment when the shortest transaction rates are highest in the maintenance period and lend their funds to other banks, creating a deficit in its reserve account, banks may also make loans and accumulate surpluses. This 'arbitration' contributes to the development of the interbank market and provides fewer fluctuations of short-term interest rates throughout the maintenance period. However, at the end of the maintenance period the established minimum level of reserves becomes binding and the banks can no longer transfer their surplus or deficit of money to the future (Mazur, 
Mazur, 2007, pp. 108-109). This fact explains the noticeable in Figure 1 jumps of EONIA rate at the end of the maintenance period.

The second function which is attributed to this instrument is increasing the structural shortage of liquidity in the banking system. The minimum reserve obligation causes the freezing of funds on the account of the central bank, and contributes to the demand for refinancing in the central bank, and it helps ECB in steering of rates of money markets through regular liquidity-providing operations (Mazur, Mazur, 2007, p. 109).

The evolution of the minimum reserve requirements is presented in Graph 2. It follows from the graph that from 1999 credit institutions have been fulfilling their minimum reserve requirements. There were no shortages of reserves in each maintenance period, there was even a surplus. In the period from 1999 until August 2009 the required reserves have increased from 98.3 billion EUR to 216 billion EUR. However, the real reserves have increased from 99.3 billion EUR to 216.9 billion EUR. The excess reserve, which is the difference between the required reserves and the real reserves, also represented an upward trend. It exceeded from 0.4 up to 2.4 billion EUR the amount of required reserves.

Figure 1. Key EBC interest rates and EONIA index

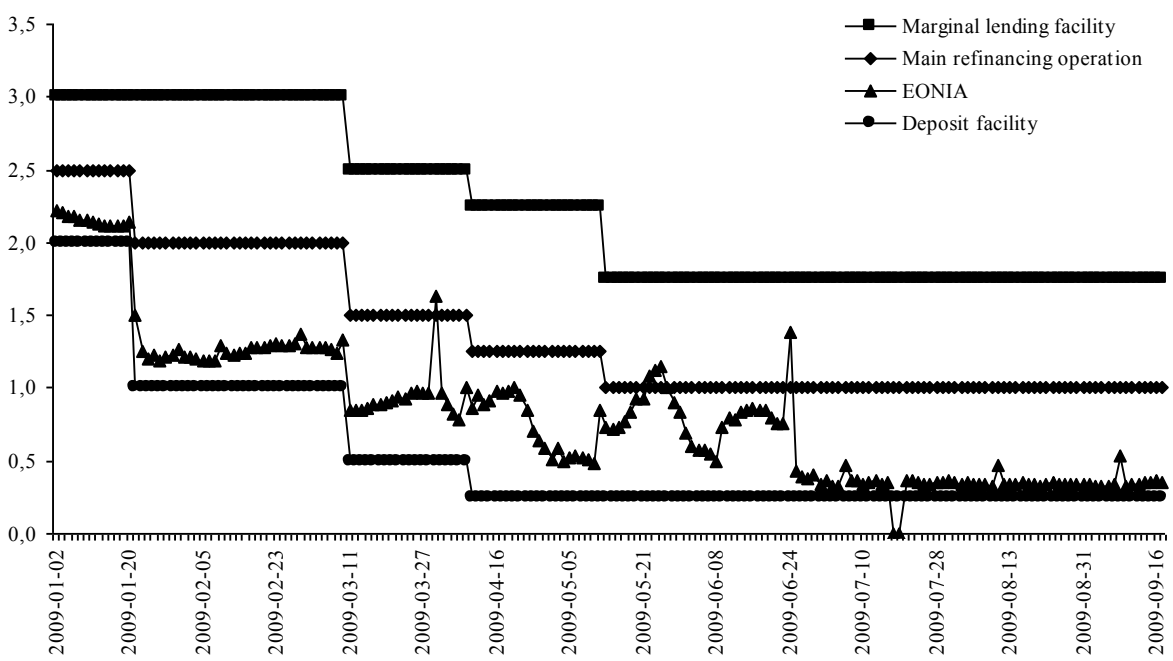

Source: Own study on the basis of the ECB data. 
Figure 2. Required reserves and credit institutions' current account (period averages of daily positions in billions EUR)

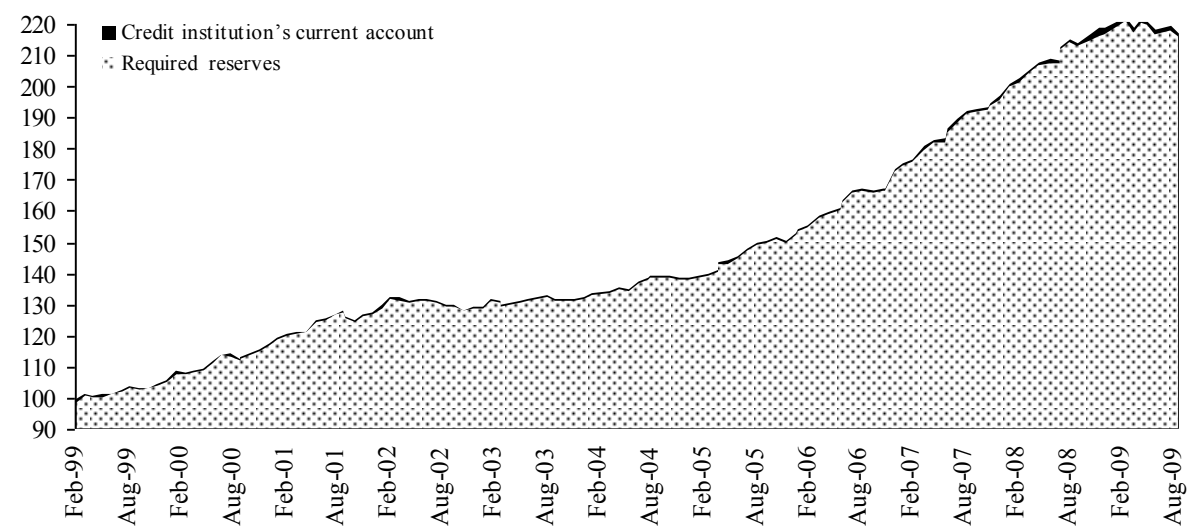

Source: own calculation based on the Monthly Bulletin, ECB for individual months of the period 1999-2009.

The upward trend of the required reserves was caused by increased liabilities forming a reserve base. In the period 1999 - August 2009 there was an increase in the stock of deposits and securities with a maturity of over two years and repos operations, to which a $0 \%$ reserve coefficient is applied. However, the liabilities of the second group (deposits and securities with a maturity up to two years), to which a $2 \%$ reserve coefficient is applied, have increased to a greater extent.

Undoubtedly, the amount of the required reserves of the Eurosystem is the determinant of an adequate level of liquidity, and thus affects the appropriate development of credit facilities by banks and non-cash money circulation. That is why it has a unique position in the consolidated balance sheet of the Euro area.

\section{The ROLE OF THE ECB'S MONETARY POLICY INSTRUMENTS IN LIQUIDITY REGULATION IN THE EURO AREA}

Based on the consolidated balance sheet of the Eurosystem, the ECB defines the surplus or shortage of liquidity. The surplus liquidity occurs when the sum of the autonomous factors in liabilities is lower than the sum of autonomous factors in the assets. By contrast, the liquidity shortage occurs if the autonomous factors on a liability side are bigger than the sum of the autonomous factors in the assets. Table 1 shows that since the start of the Eurosystem's, the liquidity shortage has occurred there. The net effect, i.e., the absorption of liquidity, which is caused by autonomous factors, consists mainly of banknotes in circulation, and then government deposits. In the period of 1999 - August 2009 banknotes in circulation 
accounted for between 50.3\% (in April, 2002) and 83.2\% (in August 2007), while government deposits between 5.3\% (in January, 2008) and 12.6\% (in June, 2009) of the total liabilities of the balance sheet of the Eurosystem. Autonomous factors in the assets have the opposite effect on the liquidity of the banking system (liquidity-providing), such as net foreign assets. During the examined period, their share in the sum of total assets ranged between 35.4\% (August, 2009) and $70 \%$ (May, 2002).

Surplus or shortage of liquidity is equalized by the EBC through the use of the monetary policy instruments. The share of the liquidity-providing instruments in the total assets of the Eurosystem was the lowest in May, $2002(30 \%)$ and largest in August, 2009 (64.6\%). The share of liquidity-absorbing instrument is often a marginal part of total liabilities, and the most significant was in January of 2009 , when it reached a record volume of $17.1 \%$. It can be concluded that the instruments of the monetary policy played a significant role in the supplying liquidity of banks, and thus, also, in shaping the size of M3 aggregates.

Among the monetary policy instruments that were used to increase the liquidity by the ECB, the main open market operations played a crucial role. The long term refinancing operations occupy a secondary position. The importance of marginal lending facility or other liquidity-providing operations is minimal. The main open market operations enjoyed most interest in August 2005 when they reached $43.9 \%$ of total assets, while the lowest in August current year, when their proportion in total assets amounted to just $7.7 \%$. The share of the long-term refinancing operations in the liquidity-providing positions has been increasing steadily since 1999 and ranges between 6.8\% (early 1999) and 56.7\% (in August, the current year) ${ }^{6}$.

Marginal lending facility is occasionally used by credit institutions of the Eurosystem in order to reduce the shortage of liquidity, and its participation in the liquidity-providing tools has not exceeded 1\% in the period between 1999 and August, 2009. Sometimes the banks decide to use other instruments enabling them to carry out their current transactions. They enjoyed the greatest success at the beginning of 1999 (when they amounted to more than $6 \%$ of total assets).

The monetary policy instruments were also used to reduce liquidity. One of them was deposit facility in a central bank. As it has been used by credit institutions on an occasional basis, its participation in liquidity absorption has not exceeded $17 \%$. Participation of other liquidity absorbing operations is low. In the tested period, they were used in the years 2004-2005, 2007-2008 (by the level at the end of the year).

${ }^{6}$ Such a high value of long-term refinancing operations in August 2009 resulted from substantial excess liquidity in the minimum reserves maintenance period ending August $11^{\text {th }}$. It was due to the fact that on $25^{\text {th }}$ June the first long-term refinancing operation was cleared with a maturity of up to 1 year and moved the time of repayment of approximately two thirds of other long-term refinancing operations (Monthly Bulletin, September 2009, ECB, p. 33). 
Among the three monetary policy instruments: minimum reserve requirements, standing facilities and open market operations, the last one is of the utmost importance. They consist in the fact that the central bank enables changing the liquidity position of credit institutions by selling them or buying from them certain securities. These transactions are carried out in tenders organized by the central bank.

Depending on the fact whether the liquidity problems are temporary or longterm ECB divides them into: main open market operations, longer-term refinancing operations, fine-tuning operations and structural operations. Open market operations can be conducted by reverse transactions, outright transactions, collection of fixed-term deposit, foreign exchange swaps or issuance of debt certificates.

Reverse transactions and outright transactions are most important. The former rely on the securities purchase agreement with the obligation to repurchase them at a specified date (repurchase agreements - repo), or on an agreement for the sale of securities with the obligation to resell them within the prescribed period (reverse repurchase agreements - reverse repo). The latter transactions are the purchase or sale of securities without creating the time for the reverse transactions with respect to these values. It should be underlined that the purchase transactions (repo or outright purchase) are liquidity-providing, and the sales transactions (reverse repo or outright sale) are liquidity-absorbing. The reverse liquidity-providing transactions are the most common in the Euro area. Since $8^{\text {th }}$ October, 2008, the weekly, main and longer-term refinancing operations have been carried out through a fixed rate tender with full allotment at the interest rate on the main refinancing operations (EBC, 9/2009, P. S8). Previously, i.e., since $28^{\text {th }}$ June, 2002 , tenders with variable interest rate have been preferable. A handful of interest rates types were announced: minimum rate, marginal rate and weighted average rate. The first is the rate at which banks could submit their bids for the purchase of securities by the central bank. The marginal rate is understood in two ways, depending on the direction of the carried out operations. In liquidity-providing (absorbing) operations, the marginal rate refers to the lowest (highest) rate at which bids were accepted. The weighted average rate is the rate at which the whole of one type of operation was conducted at an auction on a given day. Since $10^{\text {th }}$ March, 2004, the main open market operations have been carried out regularly, every Tuesday. Table 2 presents all the elements of the quota repo auction, which took place between $6^{\text {th }}$ May and $16^{\text {th }}$ September, 2009. That means that the ECB accepts all submitted bids by credit institutions at a fixed rate determined by the monetary committee. 
Table 2. Evolution of main and longer-term refinancing operations conducted by the ECB from $6^{\text {th }}$ May to $16^{\text {th }}$ September, 2009 (EUR millions)

\begin{tabular}{|c|c|c|c|c|c|}
\hline \multirow{2}{*}{$\begin{array}{c}\text { Date } \\
\text { of } \\
\text { settlement }\end{array}$} & \multicolumn{2}{|c|}{ Requirements of banks } & \multirow[b]{2}{*}{$\begin{array}{l}\text { The amount } \\
\text { of allotment }\end{array}$} & \multirow[b]{2}{*}{$\begin{array}{l}\text { Fixed } \\
\text { rate }\end{array}$} & \multirow[b]{2}{*}{$\begin{array}{c}\text { Maturity } \\
\text { date }\end{array}$} \\
\hline & $\begin{array}{c}\text { number } \\
\text { of participants }\end{array}$ & $\begin{array}{l}\text { the amount } \\
\text { of bids }\end{array}$ & & & \\
\hline \multicolumn{6}{|c|}{ Main refinancing operations } \\
\hline 06.05 & 503 & 234.197 & 234.197 & $1.25 \%$ & 7 \\
\hline 13.05 & 512 & 229.565 & 229.565 & $1.00 \%$ & 7 \\
\hline 20.05 & 558 & 221.324 & 221.324 & $1.00 \%$ & 7 \\
\hline 27.05 & 709 & 276.814 & 276.814 & $1.00 \%$ & 7 \\
\hline 03.06 & 620 & 227.576 & 227.576 & $1.00 \%$ & 7 \\
\hline 10.06 & 604 & 302.077 & 302.077 & $1.00 \%$ & 7 \\
\hline 17.06 & 670 & 309.621 & 309.621 & $1.00 \%$ & 7 \\
\hline 24.06 & 530 & 167.902 & 167.902 & $1.00 \%$ & 7 \\
\hline 01.07 & 405 & 105.905 & 105.905 & $1.00 \%$ & 7 \\
\hline 08.07 & 397 & 106.406 & 106.406 & $1.00 \%$ & 7 \\
\hline 15.07 & 389 & 100.294 & 100.294 & $1.00 \%$ & 7 \\
\hline 22.07 & 396 & 88.272 & 88.272 & $1.00 \%$ & 7 \\
\hline 29.07 & 382 & 94.780 & 94.78 & $1.00 \%$ & 7 \\
\hline 05.08 & 348 & 80.785 & 80.785 & $1.00 \%$ & 7 \\
\hline 12.08 & 320 & 73.596 & 73.596 & $1.00 \%$ & 7 \\
\hline 19.08 & 330 & 76.056 & 76.056 & $1.00 \%$ & 7 \\
\hline 26.08 & 325 & 77.530 & 77.53 & $1.00 \%$ & 7 \\
\hline 02.09 & 286 & 72.086 & 72.086 & $1.00 \%$ & 7 \\
\hline 09.09 & 311 & 93.285 & 93.285 & $1.00 \%$ & 7 \\
\hline 16.09 & 318 & 87.800 & 87.800 & $1.00 \%$ & 7 \\
\hline \multicolumn{6}{|c|}{ Longer-term refinancing operations } \\
\hline 10.06 & 147 & 56.780 & 56.78 & $1 \%$ & 28 \\
\hline 11.06 & 44 & 14.536 & 14.536 & $1 \%$ & 91 \\
\hline 11.06 & 110 & 18.202 & 18.202 & $1 \%$ & 182 \\
\hline 25.06 & 1121 & 442.241 & 442.241 & $1 \%$ & 371 \\
\hline 25.06 & 70 & 6.432 & 6.432 & $1 \%$ & 98 \\
\hline 8.07 & 86 & 38.285 & 38.285 & $1 \%$ & 35 \\
\hline 9.07 & 28 & 2.996 & 2.996 & $1 \%$ & 91 \\
\hline 9.07 & 56 & 9.067 & 9.067 & $1 \%$ & 189 \\
\hline 30.07 & 68 & 9.492 & 9.492 & $1 \%$ & 91 \\
\hline 12.08 & 90 & 30.686 & 30.686 & $1 \%$ & 28 \\
\hline
\end{tabular}


Table -2 continued

\begin{tabular}{|c|c|c|c|c|c|}
\hline \multirow{2}{*}{$\begin{array}{c}\text { Date } \\
\text { of } \\
\text { settlement }\end{array}$} & \multicolumn{2}{|c|}{$\begin{array}{c}\text { Requirements of banks } \\
\text { number } \\
\text { of participants }\end{array}$} & $\begin{array}{c}\text { The amount } \\
\text { the amount } \\
\text { of bids }\end{array}$ & $\begin{array}{c}\text { Fixed } \\
\text { of allotment }\end{array}$ & $\begin{array}{c}\text { Maturity } \\
\text { rate }\end{array}$ \\
\hline 13.08 & 20 & 13.024 & 13.024 & $1 \%$ & 91 \\
\hline 13.08 & 53 & 11.875 & 11.875 & $1 \%$ & 182 \\
\hline 27.08 & 35 & 8.321 & 8.321 & $1 \%$ & 91 \\
\hline 09.09 & 45 & 10.627 & 10.627 & $1 \%$ & 35 \\
\hline 10.09 & 14 & 3.161 & 3.161 & $1 \%$ & 91 \\
\hline 10.09 & 23 & 3.685 & 3.685 & $1 \%$ & 192 \\
\hline
\end{tabular}

Source: own study on the basis of Monthly Bulletin, September 2009, ECB, p. S8.

On the basis of the consolidated balance sheet of the Eurosystem it is possible to evaluate the effectiveness of the ECB's monetary policy instruments in regulation of liquidity. In the years 1999-2002 net foreign assets played the dominant role in the liquidity-providing factors. This meant a relatively small share of the liquidity-providing monetary instruments (only $40 \%$ of total assets). It is worth noting that during the same period other liquidity-providing operations had the largest share among the instruments of the monetary policy. This means that the ECB had to cope with a custom liquidity situation requiring immediate action. The ECB took the largest corrective action in the years 20012002. This is confirmed the ECB's problems in regulating liquidity facing autonomous factors of such a great significance. The following year there was the biggest fall of the autonomous factors, while the largest increase in the importance of the instruments (about 10 percentage points). However, only in July, 2004 , they gained an advantage over autonomous factors, reaching over $50 \%$ of total assets. During this period, the liquidity was mainly determined by the factors beyond the influence of the monetary policy. In subsequent years, the participation of the monetary policy instruments has been increasing from year to year. The monetary authorities have coped better with the shortage of liquidity and have been more effective in the control of the size.

Liquidity surplus in the banking sector in the Eurosystem is largely reduced by the autonomous factors, beyond the impact of the monetary policy. Therefore, during the examined period, the use of tools for exploitation of the liquidity surplus was insignificant (since 1999 they have not exceeded a total of $18 \%$ of total liabilities). Credit institutions current account to September, 2008 showed an upward trend. However, due to lack of confidence in the banking system after the collapse of Lehman Brothers and the mass withdrawal of bank deposits that are the basis for calculating reserves, its level shows a downward trend.

During the examined period, in the liabilities, the autonomous factors dominated over the monetary policy instruments. Credit institutions current account 
were the balancing item, determinant of the level of liquidity in the banking system. Banknotes in circulation and government deposits contributed largely to the growth in the autonomous factors. The issuance of euro banknotes showed an upward trend, but government deposits in central bank with the central banks at the same time remained relatively stable. Despite this, the autonomous factors did not grow to the same extent because of the inhibitory effect of other net factors. In the period August 2003-October 2008 their negative value was reported.

\section{Conclusions}

The method of forming of liquidity level of the national central banks participating in the ESCB is clear. Distinction of liquidity-providing and liquidity absorbing positions, allows the assessment of the effectiveness of the ECB monetary policy in the regulation of liquidity.

The changes in the liquidity-absorbing positions create simplest conditions for liquidity regulation in the Eurosystem. The share of the autonomous liquidity-absorbing factors was almost twice higher than the liquidity-providing factors, on which the EBC has no impact. Moreover, the share of liquidity-absorbing position is less volatile and is more stable rather than share of the liquidity-providing factors.

These conclusions are quite positive, heeding on the liquidity situation in the Euro area. Due to the maintaining deficit of liquidity, the increase in the importance of the instruments giving an injection of liquidity to the banking system and a simultaneous decrease of the importance of the autonomous factors operating in the same direction, but remaining outside the influence of monetary decision, are desirable. This trend occurred during the examined period. Reduction of the autonomous liquidity-absorbing factors also helps in the liquidity regulation.

\section{REFERENCES}

ECB, Monthly Bulletin, individual months of the period 1999-2009.

ECB, (2002), The liquidity management of the ECB, Monthly Bulletin, May 2002.

Knakiewicz Z., Paluszak G., (2008), Mechanizm regulowania płynności w Eurosystemie, [in:] Knakiewicz Z. (ed.), Wspótczesny pieniqdz w teorii i praktyce, Wydawnictwo Akademii Ekonomicznej w Poznaniu, Poznań 2008.

Mazur D. M., Mazur M. J., (2007), Europejski Bank Centralny a rozszerzenie Unii Europejskiej, FOSZE, Rzeszów.

NBP, (2002), Biuletyn Informacyjny 3/2002, Warsaw.

Paluszak G. (2008), Znaczenie niemieckiego system bankowego dla regulowania płynności Eurosystemu w latach 1999-2006. Wnioski dla polskiego system bankowego, [in:] Janc A. (ed.), Problemy polskiego system bankowego, Wydawnictwo Akademii Ekonomicznej w Poznaniu, Poznań 2008. 


\title{
SKuTECZNość INSTRUMENTÓW POLITYKi PIENIĘŻNeJ Europejskiego Banku Centralnego W REGULOWANIU PEYNNOŚCI EUROOBSZARU
}

Słowa kluczowe: euroobszar, płynność systemu bankowego

\begin{abstract}
Abstrakt: Mechanizm kształtowania poziomu płynności narodowych banków centralnych objętych ESBC jest przejrzysty. Opiera się na działaniach scentralizowanych i zdecentralizowanych. EBC podejmuje decyzje odnośnie do kierunku polityki pieniężnej, a narodowe banki centralne realizują politykę pieniężną zgodnie z tymi wytycznymi oraz uwzględniając warunki swojego kraju. Celem artykułu jest usystematyzowanie czynników wpływających na płynność w Eurosystemie ze szczególnym uwzględnieniem instrumentów polityki pieniężnej Europejskiego Banku Centralnego w regulowaniu płynności. Realizacji tego celu służyć ma scharakteryzowanie organizacyjnych i bilansowych powiązań banków Eurosystemu z powodu tej regulacji. Specjalny nacisk został położony na instrumenty polityki pieniężnej, które leżą w gestii narodowych banków centralnych i kształtują płynność obszaru euro.
\end{abstract}

